\section{'GreenPack-DG', a Pinkeye-type Southernpea with an Enhanced Persistent Green Seed Phenotype}

\author{
Richard L. Fery ${ }^{1}$ \\ U.S. Department of Agriculture, Agricultural Research Service, U.S. \\ Vegetable Laboratory, 2700 Savannah Highway, Charleston, SC 29414-5334
}

Additional index words. Vigna unguiculata, cowpea, blackeye bean, vegetable breeding, virus resistance

'GreenPack-DG' is a new southernpea [Vigna unguiculata (L.) Walp.] released 9 Jan. 2006 by the Agricultural Research Service of the U.S. Department of Agriculture. 'GreenPack-DG' is the first pinkeyetype southernpea to be released that has a persistent green seed phenotype conditioned by both the green cotyledon gene and the green testa (seedcoat) gene. Dry 'GreenPackDG' seeds have a richer and more uniform green seed color than dry seeds of green cotyledon phenotype cultivars, and the seeds are much less susceptible to color loss due to blanching when harvesting is delayed. 'GreenPack-DG' was developed as a replacement for 'Charleston Greenpack', a pinkeye-type cultivar with a green cotyledon phenotype that is used extensively by the frozen-food industry.

\section{Origin}

'GreenPack-DG' is the product of a pedigree-type breeding program initiated in 1997. The parental lines are 'Charleston Greenpack’ (Fery, 1998) and USVL 97-296. 'Charleston Greenpack' is a pinkeye-type southernpea that is homozygous for the $g c$ gene conditioning the green cotyledon trait (Fery and Dukes, 1994); it was developed using a backcross-pedigree breeding procedure (one backcross) involving 'Kiawah' (a pinkeye-type cultivar with cream-colored cotyledons) as the recurrent parent and 'Bettergreen' (a cream-type cultivar with greencolored cotyledons) as the donor parent (Fery and Dukes, 1988; Fery et al., 1993). USVL 97-296 is a pinkeye-type breeding line that is homozygous for the gt gene (Chambliss, 1974) conditioning the green testa trait; it is an F10 population derived from a cross between 'Kiawah' and Au 84-G-328 (a green testa, pinkeye-type breeding line developed by researchers at Auburn University). After the cross between 'Charleston Greenpack'

Received for publication 20 Oct. 2006. Accepted for publication 11 Nov. 2006.

The technical assistance of Floyd P. Maguire is gratefully acknowledged.

${ }^{1}$ To whom reprint requests should be addressed; e-mail: RLFery@saa.ars.usda.gov. and USVL 97-296, intense selection pressure was applied in F2 though F8 generations for the green cotyledon and green testa traits and superior horticultural characteristics. 'GreenPack-DG' originated as a bulk of an F8 population grown in 2003.

\section{Description}

Except for longer pods, 'GreenPack-DG' is similar in appearance to 'Charleston Greenpack'. It matures to dry-pod harvest stage at Charleston, S.C., in $\approx 63$ to $65 \mathrm{~d}$ (similar to 'Charleston Greenpack') (Table 1). The plant growth habit is low bushy. The leaf color is a dark green; the leaf surface is smooth and glossy. There is slight pigmenS.C., $2003-2005 .{ }^{2}$ complete block with 6 (Trials I-IV) or 10 replications (Trial V). tation (purple) on the stems; the petioles exhibit moderate pigmentation at the tips; the branches exhibit extensive pigmentation; and the pigmentation on the peduncles ranges from intermediate at the early pod stage to extensive at the dry pod stage. Flower color is predominately white; the upper, inside margin of the standard is lightly pigmented (violet), the base of the standard is yellow, and the wing is lightly pigmented (violet) on the back surface with a tinge of pigment (violet) on the front surface.

Pod set is concentrated, and the pods are borne above the foliage in a scattered fashion. Dry pods are attached to the peduncles in a pendant manner, and each peduncle typically produces two pods. A typical fresh-shell stage pod is slightly curved, significantly longer than either 'Coronet' or 'Charleston Greenpack' pods (Table 2), exhibits only slight constrictions between peas, and contains about 12 peas. Pod color is green when immature, dark purple when ready for maturegreen harvest, and dark straw or drab when completely dry. The upper sutures and tips of immature pods are pigmented. Fresh peas are kidney shaped and have a pink eye, quite similar to fresh 'Charleston Greenpack' peas. The dry peas have a smooth coat and are slightly smaller than those of 'Charleston Greenpack' (13.8 vs. $14.3 \mathrm{~g} / 100$ peas, respectively).

Results of 3 years of replicated field tests (five trials) at Charleston, S.C., suggest that the yield potential of 'GreenPack-DG' is comparable to the yield potential of 'Charleston

Table 1. Number of days to harvest, weight per 100 dry peas, and dry pea yield for 'Charleston Greenpack', 'Coronet', and 'GreenPack-DG' pinkeye-type southernpeas grown in five separate trials at Charleston,

\begin{tabular}{|c|c|c|c|}
\hline Trial/cultivar & $\begin{array}{l}\text { Days to harvest } \\
\text { (no.) }\end{array}$ & $\begin{array}{c}\mathrm{Wt} / 100 \text { dry peas } \\
(\mathrm{g})\end{array}$ & $\begin{array}{c}\text { Dry pea yield } \\
\left(\mathrm{kg} \cdot \mathrm{ha}^{-1}\right)\end{array}$ \\
\hline \multicolumn{4}{|l|}{ Trial 1} \\
\hline Coronet & $72.6 \mathrm{a}^{\mathrm{y}}$ & $14.6 \mathrm{a}$ & 1529 a \\
\hline Charleston Greenpack & $66.0 \mathrm{~b}$ & $13.1 \mathrm{~b}$ & $1095 \mathrm{~b}$ \\
\hline GreenPack-DG & $64.8 \mathrm{~b}$ & $13.2 \mathrm{~b}$ & $1093 \mathrm{~b}$ \\
\hline \multicolumn{4}{|l|}{ Trial II } \\
\hline Coronet & $62.7 \mathrm{a}$ & $14.2 \mathrm{a}$ & $1346 \mathrm{a}$ \\
\hline Charleston Greenpack & $61.3 \mathrm{a}$ & $13.6 \mathrm{a}$ & $1140 \mathrm{ab}$ \\
\hline GreenPack-DG & $63.0 \mathrm{a}$ & $13.6 \mathrm{a}$ & $963 \mathrm{~b}$ \\
\hline \multicolumn{4}{|l|}{ Trial III } \\
\hline Coronet & $65.0 \mathrm{a}$ & $15.1 \mathrm{a}$ & 1049 a \\
\hline Charleston Greenpack & $65.0 \mathrm{a}$ & $14.7 \mathrm{a}$ & $842 a b$ \\
\hline GreenPack-DG & $65.3 \mathrm{a}$ & $14.9 \mathrm{a}$ & $644 \mathrm{~b}$ \\
\hline \multicolumn{4}{|l|}{ Trial IV } \\
\hline Coronet & $65.3 \mathrm{a}$ & $13.5 \mathrm{a}$ & $890 \mathrm{a}$ \\
\hline Charleston Greenpack & $61.0 \mathrm{~b}$ & $14.0 \mathrm{a}$ & $791 \mathrm{a}$ \\
\hline GreenPack-DG & $63.0 \mathrm{ab}$ & $13.4 \mathrm{a}$ & $724 \mathrm{a}$ \\
\hline \multicolumn{4}{|l|}{ Trial V } \\
\hline Coronet & $65.9 \mathrm{~b}$ & $14.9 \mathrm{a}$ & $670 \mathrm{a}$ \\
\hline Charleston Greenpack & $68.4 \mathrm{a}$ & $15.2 \mathrm{a}$ & $645 \mathrm{a}$ \\
\hline GreenPack-DG & $63.2 \mathrm{c}$ & $14.0 \mathrm{~b}$ & 598 a \\
\hline \multicolumn{4}{|c|}{ Combined analysis of all trials } \\
\hline Coronet & $66.0 \mathrm{a}^{* *}$ & $14.5 \mathrm{a}^{* *}$ & $1032 \mathrm{a}^{\mathrm{NS}}$ \\
\hline Charleston Greenpack & $64.8 \mathrm{~b}$ & $14.3 \mathrm{a}$ & 872 b \\
\hline GreenPack-DG & $63.8 \mathrm{~b}$ & $13.8 \mathrm{~b}$ & $781 \mathrm{c}$ \\
\hline
\end{tabular}

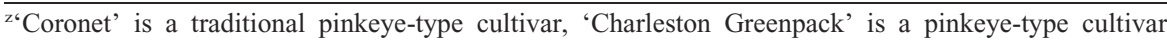
with a green cotyledon phenotype, and 'GreenPack-DG' is pinkeye-type cultivar with both the green cotyledon and green testa phenotypes. Trials I-V were planted on 12 June 2003, 21 May 2004, 14 June 2004, 23 June 2004, and 26 May 2005, respectively. Experimental design of each trial was a randomized

${ }^{y}$ Mean separation within columns and trials by the Student-Newman-Keuls multiple range test, $P \leq 0.05$. NS,*** Nonsignificant or significant interaction between cultivar and trial at $P \leq 0.01$, respectively. 
Table 2. Fresh pod length for 'Charleston Greenpack', 'Coronet', and 'GreenPack-DG' pinkeye-type southernpeas grown in two separate trials at Charleston, S.C., in 2004 and 2005.

\begin{tabular}{lccc}
\hline & \multicolumn{3}{c}{ Fresh pod length $(\mathrm{cm})$} \\
\cline { 2 - 4 } Cultivar & 2004 Trial & 2005 Trial & Combined analysis of both \\
\hline Coronet & $16.3 \mathrm{~b}^{\mathrm{y}}$ & $14.8 \mathrm{c}$ & $15.4 \mathrm{c}^{\mathrm{NS}}$ \\
Charleston Greenpack & $16.5 \mathrm{~b}$ & $16.0 \mathrm{~b}$ & $16.2 \mathrm{~b}$ \\
GreenPack-DG & $20.3 \mathrm{a}$ & $19.3 \mathrm{a}$ & $19.6 \mathrm{a}$ \\
\hline
\end{tabular}

${ }^{\mathrm{z}}$ The 2004 trial was planted on 23 June 2004; the 2005 trial was planted on 26 May 2005. Experimental design of each trial was a randomized complete block with 6 (2004) or 10 replications (2005).

${ }^{\mathrm{y}}$ Mean separation within columns by the Student-Newman-Keuls multiple range test, $P \leq 0.05$.

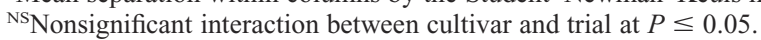

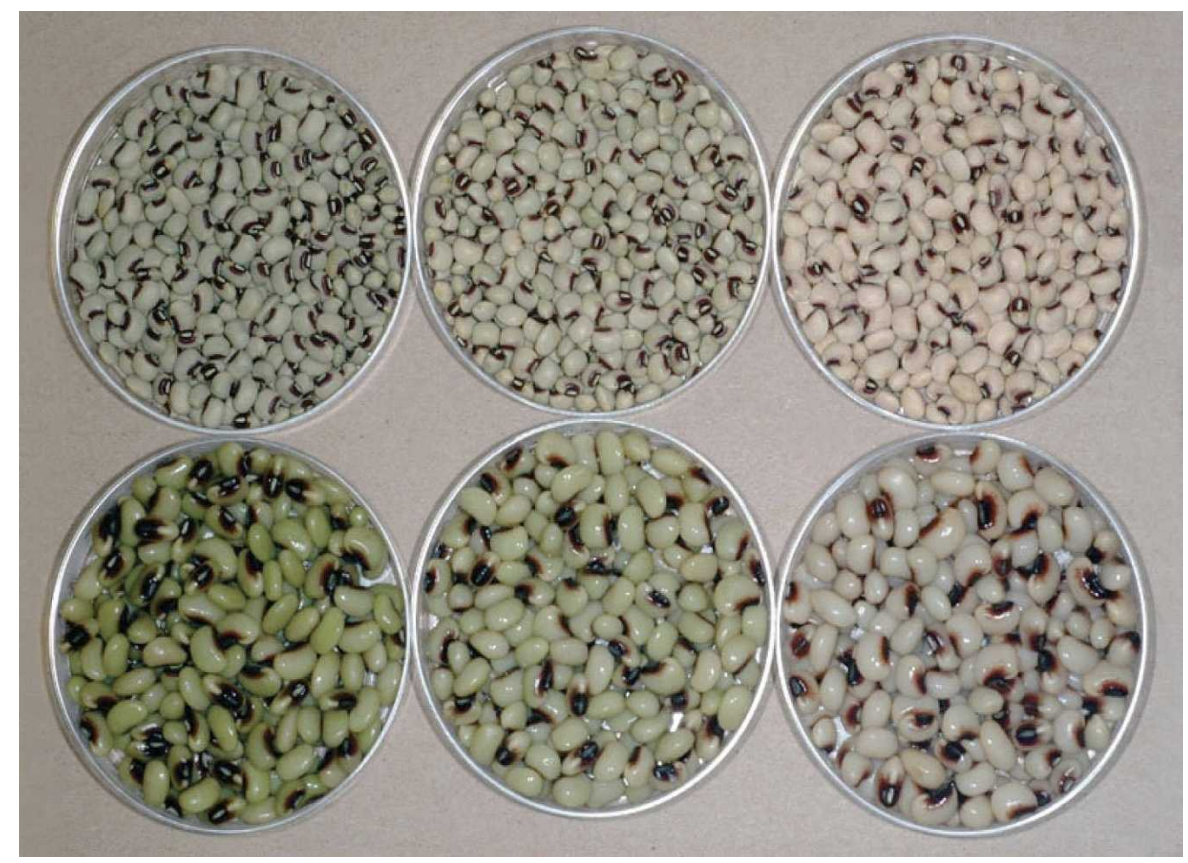

Fig. 1. Dried seeds (top) and dried seeds imbibed to restore fresh-harvest seed size and blanched in boiling water for 3 min (bottom) of 'GreenPack-DG' (left), 'Charleston Greenpack' (center), and 'Coronet' (right). Note the enhanced green color of both the dried and imbibed seeds of 'GreenPack-DG' ( $g c / g c g t / g t)$, the green color of both the dried and imbibed seeds of 'Charleston Greenpack' $(g c / g c$ $G t / G t)$, and the cream color of both the dried and imbibed seeds of 'Coronet' $(G c / G c G t / G t)$.

Greenpack'. 'GreenPack-DG' yields did not differ from 'Charleston Greenpack' yields in any of the five trials (Table 1). The results of the combined analysis, however, did separate the 'GreenPack-DG' and 'Charleston Greenpack' yields. Like 'Charleston Greenpack', the yield potential of 'GreenPack-DG' tends to be less than that of 'Coronet'.

'GreenPack-DG' is homozygous for the $g c$ gene that conditions the green cotyledon trait and the $g t$ gene that conditions the green testa trait. The primary color of field-grown 'GreenPack-DG' peas harvested at the dry stage of maturity is a rich olive green (Fig. 1). Dry 'GreenPack-DG' seeds imbibed to restore fresh-harvest size and blanched in boiling water for 3 min exhibit a uniform green color. A major attribute of the new cultivar is the persistence of the green color of unharvested to arrange for evaluation of the suitability of the harvested products for commercial processing, and to test for field resistance to blackeye cowpea mosaic virus (B1CMV). Performance in these plantings was consistent with the performance of the replicated trials at Charleston, S.C. Peas harvested at the dry seed stage produced a frozen product with excellent characteristics, and the results of inoculated field plantings indicate that the new cultivar has excellent field resistance to B1CMV. 'GreenPack-DG', like 'Charleston Greenpack', does not produce hard seeds that are troublesome to frozen-food processors.

'GreenPack-DG' is recommended for evaluation by the frozen-food industry as a replacement for 'Charleston Greenpack'. It should perform well in all areas where 'Charleston Greenpack' has been grown successfully. The seed shape, seed size, and seed eye pattern traits of the new cultivar are quite similar to those of 'Charleston Greenpack'; seeds of the two cultivars can be readily blended (packed together) to produce a retail product with the desired intensity of green color.

\section{Availability}

Protection for 'GreenPack-DG' is being sought under the Plant Variety Protection Act. 'GreenPack-DG' was developed under a Cooperative Research and Development Agreement with Western Seed Multiplication (WSM), 2484 S.I.Y.C. Road, Wadmalaw Island, S.C. 29487, and WSM has been granted the right of first refusal to an exclusive license to market the new cultivar. Genetic material of this release will be deposited in the National Plant Germplasm System, where it will be available for research purposes, including development and commercialization of new cultivars. It is requested that appropriate recognition of source be given when this germplasm contributes to research or development of a new breeding line or cultivar. the green cotyledon phenotype parent 'Charleston Greenpack', which must be harvested immediately after pod drying to ensure a high-color product, 'GreenPackDG' has a considerably larger harvest window. Color loss is a critical problem in production systems where preharvest chemical desiccants are used to facilitate mechanical harvesting operations. The 7-d delay between application of the desiccant and initiation of harvesting operations can result in serious color degradation.

'GreenPack-DG' was grown "on-farm" in South Carolina, New Mexico, and in California during 2004-2005 by Western Seed Multiplication (Wadmalaw Island, S.C.). The purpose of these plantings was to multiply seed, to evaluate field performance,

\section{Literature Cited}

Chambliss, O.L. 1974. Green seedcoat: a mutant in southernpea of value to the processing industry. HortScience 9:126.

Fery, R.L. 1998. 'Charleston Greenpack', a pinkeye-type southernpea with a green cotyledon phenotype. HortScience 33:907-908.

Fery, R.L. and P.D. Dukes. 1988. 'Kiawah' southernpea. HortScience 23:645-646

Fery, R.L. and P.D. Dukes. 1994. Genetic analysis of the green cotyledon trait in southernpea. [Vigna unguiculata (L.) Walp.]. J. Amer. Soc. Hort. Sci. 119:1054-1056.

Fery, R.L., P.D. Dukes, and F.P. Maguire. 1993 'Bettergreen' southernpea. HortScience 28:856. 